\title{
The Progressive ApProaches and Risks in Evaluating the Development Potential OF THE AREA
}

\author{
BETAKOVA, J.; LORKO, M. \& SKODA, M.
}

Abstract: The paper deals with analysis of selected progressive approaches to effective use and evaluation of area development potential. The object of this study was to analyze and evaluate effectiveness of selected processes and tools of spatial management and their impact on development of settlement structures. Research methodology was subject to monitoring the environmental aspects of area. Based on comprehensive in-depth analysis, we concluded that progressivity of approach lies in selection of appropriate planning methods and tools in order to extend methodological bases for their mutual interaction in individual stages and levels of regional planning and development of settlement structures. The aim of the research was to evaluate potential risks in implementation of selected environmental management tools and their impact on development potential of the area.

Keywords: Safety risks, Globalization, Urban settlement
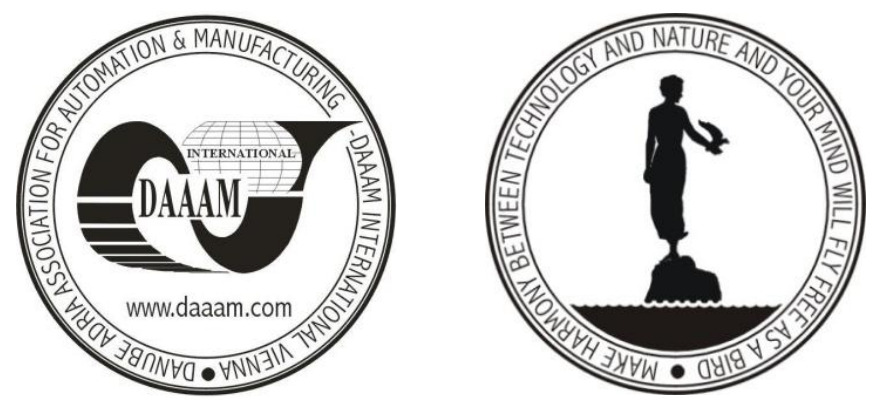

Authors' data: Ass. Prof. Dr. Betakova, J[anka]; Dr. Lorko, M[artin]; CSc. Škoda, M[iroslav], Technology Institute in Dubnica, Dubnica nad Vahom, Sladkovicova 533/20, 01841 Dubnica nad Vahom, Slovakia, betakova@dti.sk, lorko@dti.sk, skoda@dti.sk

This Publication has to be referred as: Betakova, J[anka]; Lorko, M[artin] \& Skoda, M[iroslav] (2014). The Progressive Approaches and Risks in Evaluating the Development Potential of the Area, Chapter 36 in DAAAM International Scientific Book 2014, pp.449-458, B. Katalinic (Ed.), Published by DAAAM International, ISBN 978-3-901509-98-8, ISSN 1726-9687, Vienna, Austria

DOI: $10.2507 /$ daaam.scibook.2014.36 


\section{Introduction}

Effectiveness, flexibility and ability to respond current requirements and conditions in territorial development represent high current topic not only within

Slovakia. Finka (2010) As stipulated in Leipzig Charter on Sustainable European Cities (2007), urban development integrated policy is the process in which coordination of territorial, thematic and temporal aspects, as well as key areas of urban policy emerge. Urban development integrated policy is key condition and prerequisite for implementation of the European Strategy of Sustainable Development. It represents agenda of European dimension based on principle of subsidiary where local conditions and needs have to be considered. In this respect, the following finding is worthy, i.e. that regions represent the basis of national competitiveness because the direct confrontation between knowledge creators and their users emerges at their levels. In this context, the Leipzig Charter on Sustainable European Cities (2007) states that alignment of interests that is enabled through the policy of integrated municipality development, constitutes viable basis for consensus between government, regions, municipalities, citizens and economic actors.

Resulting from affirmation by Hudakova et al. (2014), as well as in this context, economic development in market economies is intertwined to concept of competitiveness being the benchmark of long-term success of companies, as well as countries and their regions, resp. municipalities. We agree with statements by Kraftova et al. (2013) that theoretic, methodological and practical issues of company competitiveness have been fairly well-defined in economic theory. However, as far as regional competitiveness is concerned, situation is different, despite present significant emphasizing of regional dimension in analytical and theoretical works. Tvrdon (2013) points out the fact of increasing importance of necessity to study and explore the space due to increasing need of effective tools for solving new problems upon established principles, as e.g. territorial cohesion or new normative approaches within the E.U. that are listed in the E.U. official documents being in compliance with other principles of the Lisbon Treaty.

\section{Development trends and their area and spatial impacts}

Spatial development as comprehensive phenomenon of society development takes place within complex interactions between social and economic, social and ecological, resp. social and cultural dimensions, reflecting in formulating the objectivism of planning systems focused to management of this development in order to ensure its sustainability. In this context, we start from assumptions by Finka (2010) generating clearly contemporary development trends as advancement from planning tool system to the one of area development management, resp. spatial development, as well as advancement from planning the area effective utilization/exploitation and its structural development regulation to integrated spatial planning. Trends of spatial management tools are defined by him as follows: 


\begin{tabular}{|c|c|c|}
\hline & $\begin{array}{c}\text { From management } \\
\text { tools }\end{array}$ & To management tools \\
\hline \multirow{4}{*}{$\begin{array}{c}\mathrm{C} \\
\mathbf{O} \\
\mathrm{N} \\
\mathrm{T} \\
\mathrm{E} \\
\mathrm{N} \\
\mathrm{T}\end{array}$} & Sector & complex/global \\
\hline & Sector & integrated \\
\hline & Balancing & spatial- space as quality rate \\
\hline & status-oriented & processual, focused to process management \\
\hline \multirow{5}{*}{$\begin{array}{c}\mathrm{M} \\
\mathrm{E} \\
\mathrm{T} \\
\mathrm{H} \\
\mathbf{O} \\
\mathrm{D} \\
\mathbf{O} \\
\mathrm{L} \\
\mathbf{O} \\
\mathbf{G} \\
\mathrm{Y}\end{array}$} & Mandatory & participatory \\
\hline & Routine & knowledge based \\
\hline & $\begin{array}{l}\text { ecologizing (economy } \\
\text { managing) } \\
\end{array}$ & $\begin{array}{c}\text { economizing (environmental aspects integrated in } \\
\text { process management of self-organization) }\end{array}$ \\
\hline & managing/contr. & negotiating \\
\hline & Polarizing & $\begin{array}{l}\text { profiling selectively/specific/based on } \\
\text { cooperation and competition }\end{array}$ \\
\hline \multirow{5}{*}{$\begin{array}{l}\mathbf{A} \\
R \\
E \\
A\end{array}$} & discrete and sequential & permanent-continual-processual \\
\hline & ex-post reacting & ex-ante oriented \\
\hline & Local & regional \\
\hline & National & regional \\
\hline & Inside the oriented & oriented interactively \\
\hline
\end{tabular}

Tab. 1. Trends of spatial management tools, (Finka, 2010)

In order to activate economic capital inflow, municipalities and regions seek new forms of cooperation enabling more effective use of their development potential. For the purpose of territorial development coordination, the following basic development lines have been adopted: balanced polycentric system of municipalities with new conception of relationship between city and countryside, equal access to infrastructure and knowledge/information, sustainable development and protection of natural and cultural heritage.

\section{Polycentric concept and partnerships}

Spatial concentration represents current dominant trend resulting in effort to find ways how to eliminate its negativistic impacts. One of potential solution is also 
conception of polycentric and harmonic development that is response to increasingly urgent needs of solving the differences in competitiveness between the E.U. central parts and its peripheral ones (Simak, 2004). Minimization of increasing contradiction between economic effectiveness, individual freedom of choice and unequal territorial and spatial conditions is subject to implementation of optimal territorial organization/setup that would support complementarities, cooperation, as well as optimal use of potentials while preserving the specifics and specific development limits.

Conception contained in the European Spatial Development Perspective (ESPD) plays significant role in coordinated spatial development of Europe, where polycentric system of settlement is declared as essential principle of settlement systems. Cities, in effort to increase their attractiveness, will have to build on cooperation, partnerships and coordination of their development with villages not only in their close neighborhood. Kelisek et al. (2011) draws attention to fact that they will have to learn to coexist in so-called cooperative competition where, despite their mutual competition, they will have to attract and gain capital resources and investments for common good.

Policy of integrated urban development engages actors, including public administration and enables the citizens to play active role in modeling their close environment Leipzig Charter on Sustainable European Cities (2007). That is also the reason why, in the course of last decades, so much attention has been paid to social capital as significant factor of economic development that is associated with changes which the structures of economy and society have been through. Social capital is seen mutually beneficial for the individual, as well as for community. Holla et al. (2013) defines social capital as investment in social relations with expectable recovery on the market, while it can be understood as economic, political or labour market, alternatively community, as well. Sikula (2010) characterizes social capital in a very simply way. While economic capital is on bank accounts of people and human capital is in their heads, social capital dwells in the structure of their relations. Strussova et al. (2009) states that social capital can be considered as the set of social relations that may be exploited anytime by any single entity (e.g. entrepreneur, resp. worker) or by any collective one (public, resp. private). Thus, throughout availability of this relation capital, cognitive resources (e.g. information) and normative ones (e.g. trust) are able to implement objectives that would be achievable on much higher costs, resp. unfeasible.

Partnership principle is currently ranked among basic principles of the E.U. structural policy, whereas the manner of its implementation in particular country depends on overall implementation of structural policy within selected country. Ability to implement new partnership may include development incentives; on the contrary, their absence becomes a brake of future development. Partnership principle implementation tends to establish close cooperation between European, national and local institutions which participate in regional policy formation. In this context, Hamalova, M., Belajova, A. (2011) state that experience connected with elaborating national programs of regional development in the E.U. member countries show low real rate of regional engagement in their formation process, as well as frequent institutional separation of planning, resp. implementation process. 
Analogical situation occurs generally at formation and implementation of program documents at regional, resp. municipality levels.

\section{Survey methodology and objectives}

Object of presented study is to analyze and evaluate effectiveness of spatial management selected tools in terms of the Slovak Republic in the context of sustainable development of the Biele Karpaty Euro region. Goal of paper was to analyze implementation of polycentricism model in connection to making partnerships in context of increasing the competitiveness potential of the Biele Karpaty Euro region.

Whole study is based on assumption that the spatial quality and associated time and spatial continuity of planning the development activities are integrating factors for effective territorial development compatible with sustainable development goals. Principle of sustainability makes presumption and starting point/fundamental basis for evaluation of territorial development potential in context of generating the potential risk emergency in order to prevent negative impacts on urban development. Complex research was conducted within the KEGA Project No. 005 DTI-4-2014, Sector Integration of Spatial Impacts of Safety Management, and Environmental Risks. Resulting from casual survey study (selected sample of 180 respondents) dealing with risk perception endangering the respondents' safety within concerned Euro region Biele, resp. Bile Karpaty, partial objective has been generated that is determination of identity or diversity of selected risk mean values within studied Euro regions. In order to meet the set goals, we have used empirical methods of research (questionnaire), statistics method, i.e. variance analysis using quantitative statistical tools (per cents, average values, variance, Cochran's test, KolmogorovSmirnov test, F-test, Kruskal-Wallis test, as well as the Statgraphics centurion,2014). Individual risk values have been expressed in scale from 1 to 11 . The variance analysis of selected risks plays significant role in analyses, as well as at evaluation of selected risks. The analysis itself consists of the following stages:

- Calculation of selected characteristics (mean value, variance) from the concerned casual study within selected euro regions, resp. risks.

- Decision on suitability of application between parametric or non-parametric tests in risk variance analysis in respect to terms set for their performance.

- Testing the variance hypotheses of selected risks using parametric F-test, resp. non-parametric Kruskall-Wallis test and thus, determining if mean values of selected risk between Euro regions are identical.

In our paper, logical research methodology has been applied, e.g. comparative method, analytic and systematic method for studying individual tools of environmental management, induction, resp. deduction method for making conclusions. As far as basic research method is concerned, complex analysis based on system analysis theory, resp. on synthesis of theoretic and empiric research procedures can be considered. Determinants of current urban structure development 
Betakova, J.; Lorko, M. \& Skoda, M.: The Progressive Approaches and Risks in Ev...

have been approached and studied systematically, using methods of complex spatial evaluation, comparison, economic analyses, as well as statistical ones.

Goal of our partial research was to evaluate potential risks at implementation of environmental management selected tools, resp. their effect on territory development potential. Another partial objective that is dealt with in presented study was the analysis of facts:

- Identification of the most significant partnership forms contributing to implementation of social and economic development of the Biele Karpaty Euro region.

- Analysis of safety perception as category of life quality in the context of spatial quality and value scales of individual actors involved in this development process from the point of view of particular target groups.

- Utilization of participatory potential by residents of the Biele Karpaty Euro region from the both sides of border, i.e. the Czechs, as well as the Slovaks, while implementing the environmental management selected tools in the context of territorial sustainable development.

In the work being presented, logical research methodology has been applied: comparative method, analytic and synthetic method for studying individual tools of environmental management, induction, resp. deduction method for making conclusions. The basis of research methodology results from principle of multi-level complex analysis, selected activities and factors effecting the urban structure development. The processing itself has been divided into three development stages:

- Analysis of theoretical knowledge, as well as practical experience compatible with implementation of spatial management selected tools and their spatial impacts on urban structure development.

- Analysis, quantification and application of qualitative methods at evaluation of synergic and cumulative impacts in context of sustainable development and planning mechanism system.

- Summary of conclusions for application of progressive approaches to assessment of urban unit development potential.

\section{Variance Analysis of Selected Risks in the Euro region}

Basic selected characteristics are shown in tables beneath, e.g. mean value, resp. variance as follows:

\begin{tabular}{|l|c|c|c|c|c|c|}
\hline \multirow{2}{*}{$\begin{array}{c}\text { EURO } \\
\text { REGION }\end{array}$} & $\begin{array}{c}\text { Political } \\
\text { [scale] }\end{array}$ & $\begin{array}{c}\text { Legal } \\
\text { [scale] }\end{array}$ & $\begin{array}{c}\text { Military } \\
\text { [scale] }\end{array}$ & $\begin{array}{c}\text { Safety } \\
\text { [scale] }\end{array}$ & $\begin{array}{c}\text { Social } \\
{[\text { scale] }}\end{array}$ & $\begin{array}{c}\text { Ecological } \\
\text { [scale] }\end{array}$ \\
\hline BIELE K. & 2,75 & 4,84 & 6,04 & 2,34 & 5,22 & 10,17 \\
\hline BÍLE K. & 5,14 & 6,98 & 8,74 & 7,65 & 9,87 & 10,36 \\
\hline
\end{tabular}

Tab. 2. Mean Risk Values in the Biele Karpaty Euro region 


\begin{tabular}{|l|c|c|c|c|c|c|}
\hline \multirow{2}{*}{$\begin{array}{l}\text { EURO } \\
\text { REGION }\end{array}$} & $\begin{array}{c}\text { Political } \\
\text { [scale] }\end{array}$ & $\begin{array}{c}\text { Legal } \\
\text { [scale] }\end{array}$ & $\begin{array}{c}\text { Military } \\
{[\text { scale] }}\end{array}$ & $\begin{array}{c}\text { Safety } \\
{[\text { scale] }}\end{array}$ & $\begin{array}{c}\text { Social } \\
{[\text { scale] }}\end{array}$ & $\begin{array}{c}\text { Ecological } \\
{[\text { scale] }}\end{array}$ \\
\hline BIELE K. & 3,69 & 4,78 & 1,84 & 8,14 & 4,18 & 2,18 \\
\hline BÍLE K. & 4,89 & 5,45 & 2,35 & 2,17 & 3,39 & 1,86 \\
\hline
\end{tabular}

Tab. 3. Risk Value Variance in the Biele Karpaty Euro region

Variance Analysis has been performed using parametric F-test, resp. nonparametric Kruskall-Wallis test. Parametric test can be performed subject to the two following conditions:

- Homoscedasticity - identical risk variances between Euro regions. Results are summarized in Tab. 4.

- Value normality - probability model of normal/standard division of risk values within individual Euro regions. Results are summarized in Tab 5.

Non-parametric Kruskall-Wallis can be performed subject to presence of variance homoscedasticity. However, risk values within individual sectors are not divided in normal/standard way.

\begin{tabular}{|c|c|}
\hline Risk & Cochran`s test [P-value] \\
\hline Political & 0,158 \\
\hline Legal & 0,598 \\
\hline Military & 0,087 \\
\hline Safety & 0,004 \\
\hline Social & 0,814 \\
\hline Ecological & 0,154 \\
\hline
\end{tabular}

Tab. 4. Cochran`s test of verifying the homoscedasticity

\begin{tabular}{|c|c|}
\hline Risk & Pearson's chí-test [P-value] \\
\hline Political & 0,004 \\
\hline Legal & 0,012 \\
\hline Military & 0,195 \\
\hline Safety & 0,651 \\
\hline Social & 0,038 \\
\hline Ecological & 0,019 \\
\hline
\end{tabular}

Tab. 5. Pearson's $\chi^{2}-$ test of verifying risk value normality

As resulting from Cochran's test, the hypothesis on identical variances of political, legal, military, social, as well as ecological risks between individual Euro regions is acceptable with 95 per cent probability. As for heteroscedasticity, variance diversity of safety risk between the Euro regions - 95 per cent probability.

As resulting from Pearson's $\chi^{2}-$ test, values of military and safety risk are divided normally within the Euro regions at the level of 5 per cent significance. As 
Betakova, J.; Lorko, M. \& Skoda, M.: The Progressive Approaches and Risks in Ev...

far as the values of political, legal, social and ecological risks are not divided normally within the Euro regions of the casual study.

Based on the results as mentioned above, we claim impossibility to perform variance analysis of safety risk using either parametric or non-parametric tests.

\begin{tabular}{|c|c|}
\hline Risk & F- test \\
\hline Military & 0,0007 \\
\hline
\end{tabular}

Tab. 6. Parametric F-test of Risk Variance Analysis

\begin{tabular}{|c|c|}
\hline Risk & $\begin{array}{c}\text { Kruskall-Wallis test }[\text { P- } \\
\text { value }]\end{array}$ \\
\hline Political & 0,021 \\
\hline Legal & 0,014 \\
\hline Social & 0,034 \\
\hline Ecological & 0,519 \\
\hline
\end{tabular}

Tab. 7. Non-parametric Kruskall-Wallis Test of Risk Variance Analysis

Primary result interpretation on risk analysis from Table 6 and 7:

- Hypothesis that military risk mean values are different in Euro regions of casual study is acceptable with 95 per cent probability.

- We can infer 95 per cent probability that there are statistically significant differences between medians of political, legal and social risks within Euro regions. That is why we reject hypothesis on identity of their variances.

- We claim the most significant differences among n-values of safety risk in Euro regions with 95 per cent probability.

- There are no statistically significant variances in values of ecological risk medians (importance rate 5 per cent). Reasonably, we accept hypothesis on identity of medians and their variances between Euro regions Biele and Bile Karpaty.

\section{Evaluation and Discussion}

Twenty years after the former Czecho-Slovak Republic split-up we would characterize previous period through changes that have exposed a significant impact on categorization of citizens values, in the context of developing their subjective points of view on actual development condition, as well as on society value categories.

The process of development has also brought about dynamical and turbulent development changes in generating and forming the value orientation of subjects being parts of it. The survey has been seeking answers on question: "What is the rate of citizens', resp. other relevant economic entities' participation in management of public affairs within the system of values, standards and expectations that effect their attitudes, approaches, resp. behavior?" As resulting from survey, we can confirm that Slovakia has expanded space for authentic citizen's participation. However, despite this fact, the citizens do not care for this opportunity due to failure in constitution of new participial democratic civic culture. They pay more attention 
to effects, resp. results of real implementation of development processes being brought by this trend and prefer it to participation in them. Primary survey results completed with secondary information findings create premise for the following conclusions:

- All the survey participants find partnerships the prerequisite for achieving the regional development objectives.

- Basic motivational factors to constitute partnership include conditions for disbursement of Euro funds.

- Self-governing institutions fail to use the partnership principle in optimal rate, especially in relation with private sector at initiation, creation and realization stages of development policy implementation, as well as at complex usage of the E.U funds in compliance with operational and regional plans.

- Nevertheless, partnership principle is implemented into creation of development planning materials, programmers of economic and social development in minimum rate due to persistent administrative approaches.

As resulting from the survey, the municipalities have realized necessity of more significant participation of public entities, businesses, non-profit organizations, as well as citizens in development process of territory. However, mechanisms for systematic, long-term and fair collaboration between potential partners of these processes is still absent.

\section{Conclusion}

Discussions, as well as various speculations on the Slovak development and orientation have a common denominator for which is characteristic seeking new development ways and compromises between sustainability of economic effectiveness tending to competitiveness and quality of life sustainability. The global objective is to reach such quality of life for citizens using changes in individual spatial structures that would create conditions for enforcement of friendly forces to knowledge and innovation. It would eliminate insignificant regional disparities in long-term course. Modern, flexible, effective and efficient public administration constitutes prerequisite for implementation of objectives and development conditions in order to increase competitiveness, as well as activation of endogen development potential of regional and territorial development. Metropolitan areas represent the economic powerhouses and creativity and innovation centres. They are keys of regional development and goal achievements of Lisbon and Goteborg. In the same time, these areas focus to basic challenges and problems that the European Union will have to face in following years. The weak points that obstruct balanced development of metropolitan areas are lack of identity, compatible social and economic, resp. environmental information on these areas that could be comparable at the European level.

The constitution of necessary partnership is prerequisite for success of metropolitan areas at national, regional and local levels. It requires legitimacy of decentralized institutions that will ease the initiatives of private sector, as well as non-governmental institutions. So that this conception of polycentric development could become the starting point for territorial development regulation, it ought to be 
Betakova, J.; Lorko, M. \& Skoda, M.: The Progressive Approaches and Risks in Ev...

operationalized. First steps in these areas have been stipulated in basic spatial policy documents of territorial planning. To follow-up them, the polycentric concept should be included into strategic documents of regional policy. Our paper has ambition to contribute to extension of scientific and professional platform on these processes.

\section{Acknowledgements}

The authors would like to thank the Ministry of Education of the Slovak Republic for their support in the grant project KEGA Project No. 005 DTI-4/2014.

\section{References}

Finka, M., 2010: Inspiration of the legal environment management spatial development of European States, In: Urbanite 1/2010, No.1, pp.12-17, ISSN 01395912

Hamalova, M., Belajova, A., 2011: Communal Economy and Policy, In: Sprint, Bratislava 2011, p. 260, ISBN 978-80-89393-38-1

Hudakova, M., Buganova, K., Luskova, M., 2014: Small and Medium- $\quad$ Sized Enterprises Business Risks in Slovakia. In: WMSCI 2014: The 18th World MultiConference on Systemics, Cybernetics and Informatics, Orlando, Florida, USA, 2014. ISBN -13: 978-1-941763-05-6. S. 240-245

Leipzig Charter on Sustainable European Cities, 2007, Online in: http://www.eukn.org/binaries/eukn/eukn/policy/2007/8/leipzig-charta-adr-sk.pdf

Kelisek, A., Klucka, J., Ondrusek, M., Strelcova, S., 2013: Economic security A principal component of multilevel security concept in global economy. Communications, ZU v Zilina, 2011, pp. 44-48, ISSN 1335-4205

Kraftova, I., Applova, P., 2013: Development of competition and the Regions byvalet GDR and Czechoslovakia, In: Valtice 2013, Masaryk university 2013, ISBN 978-80210-6257-3

Holla, K., et al., 2013: Complex model of risk assessment of industrial processes MOPORI. n: Communications: scientific letters of the University of Zilina. - ISSN 1335-4205. - Vol. 15, no. 2, 2013, 9pp. 63-68

Strussova, M., Petrikova, D., 2009: Possibilities and preconditions of civic participation in sustainable settlement development. Sociology 41, 2009, č. 4, ISSN 1336-8613

Sikula, M. 2010: The long-term vision of the development of Slovak society, A Long-Term Vision of the Slovak Society Development. In: Bratislava EU SAV 2010. p. 274, ISBN 978-80-7144-168-7

Simak L., 2004: Crisis management in public administration, Faculty of security engineering, University of Zilina, Zilina 2004 ISBN 80-88829-13-5

Statgraphics: Software Statgraphics Centurion XV. 2014 [online], [cit. 2014-7-11], Available at: http://www.statgraphics.com/support/download_center.aspx

Tvrdon, J., 2013: Reality in the mirror of conceptual regional development approaches. In: Valtice 2013, Masaryk University, pp.17-22, ISBN 978-80-210$6257-3$ 